\title{
NOT PROFITING FROM PRECARITY: THE WORK OF NONPROFIT SERVICE DELIVERY AND THE CREATION OF PRECARIOUSNESS ${ }^{1}$
}

\author{
Donna Baines \\ Professor, \\ School of Labour Studies and \\ School of Social Work, \\ McMaster University, \\ Hamilton, Ontario, Canada \\ bainesd@mcmaster.ca \\ John Campey \\ Executive Director, \\ Social Planning Toronto, \\ Toronto, Ontario, Canada \\ jcampey@socialplanningtoronto.org
}

\author{
Ian Cunningham \\ Professor, \\ Department of Human Resource \\ Management, \\ Strathclyde Business School, \\ University of Strathclyde, \\ Glasgow, Scotland, United Kingdom \\ ian.cunningham@strath.ac.uk \\ John Shields \\ Professor, \\ Department of Politics and Public \\ Administration, \\ Ryerson University, \\ Toronto, Ontario, Canada \\ jshields@ryerson.ca
}

\begin{abstract}
This paper examines the impact of precarity on the nonprofit service providing sector (NPSS). Using in depth qualitative interviews, recent empirically-based surveys of the Ontario nonprofit sector and key academic and grey literature, we explore the deeper meaning of precarity in this sector. We contend that the NPSS is a unique, and in many respects, an ideal location in which to explore the workings and impact of precarity. Looking at the nonprofit sector reveals that precarity operates at various levels, the: 1) nonprofit labour force; 2) organization structure and operation of nonprofit agencies; and, 3) clients and communities serviced by these nonprofit organizations. By observing the workings of precarity in this sector, precarity is revealed to be far more than an employment based phenomenon but also a force that negatively impacts organizational structures as well as vulnerable communities.
\end{abstract}




\section{INTRODUCTION}

[...] the people doing this kind of work [with vulnerable youth] are more often than not contract workers, so how does that impact the population of youth they are coming in contact with? Well, it sucks because youth needs stability and the impact [is felt] if the funding bodies change ... And so what ended up happening is I had to actually step away from all the organizing and activism I was doing because it was burning me out, because I was trying to manage my own precarity. (Female visible minority nonprofit sector youth worker)

s captured in the above reflection, the impact of precarity within the
nonprofit service providing sector (NPSS) is quite profound,
operating with negative consequences along various dimensions. At its core, precarity is concerned with the lack of security and/or predictability, most particularly as it relates to employment. The NPSS in Canada offers, in fact, a unique, and in many respects, an ideal setting in which to examine the workings and impacts of precarity. Precarity operates on at least three levels within the NPSS; that of the: 1) nonprofit labour force, 2) organizational structure and operation of nonprofit agencies, and 3) clients and the community serviced by these nonprofits. For example, many marginalized communities rely on the services provided by nonprofit providers and are closely linked to the service workers who are very often drawn from their ranks. Consequently, the sector is strategically situated to reflect upon the impact that employment precarity has had upon the vulnerable communities that these non-profit providers serve. Moreover, the NPSS workforce itself is one that is characterized by high levels of precarity due to such factors as inadequate and unstable government funding. The added value that this analysis offers is the ability to move beyond employment precarity and to uncover precarity's impact at other levels and also to identify the self-reinforcing nature of their layered interaction. Precarity has come to be pervasive in many parts of life and is a major defining feature in our 'age of insecurity' (Elliott and Atkinson 1999).

An examination of the nonprofit service providing sector, consequently, allows us insight into the nature and effects of employment precarity among nonprofit providers themselves, as well as the impact of precarity within the broader communities they service (Richmond and Shields 2004; Baines 2004; Community Social Planning Council of Toronto et al. 2006).

\section{THE NPSS}

The NPSS is a subsector of the larger nonprofit sector which is very diverse and expanding, ranging from advocacy to religious organizations, voluntary sports groups to parent school-based associations, and from arts and culture organizations to social, health and human service provision agencies. The core 
nonprofit sector in Canada is large and growing, standing at about 2.5 percent of GDP. It constitutes a substantial economic force, being, for instance, substantially bigger than the auto and agricultural sectors (Statistics Canada 2007: 10, 13). Nonprofit service providers are situated between the state and market sectors and are defined by their orientation to serve a public or group good, but through private nonprofit-making organizational forms (i.e., third sector formations). The NPSS embodies these characteristics and is driven by a caring mission to do good works in the service of its clients and community base.

The services-providing component of the sector constitutes between a quarter to a third of the Ontario nonprofit sector (MCI 2013: 28; McIsaac et al. 2013b: 10). This element of the sector is key, not just because of its size, but also because of its relationship with the state and civil society in providing publically supported services and programs, especially to vulnerable clients and communities. The NPSS is also "human resource intensive; indeed, human capital is viewed as being the 'greatest strength' of non-profit organizations" (McMullen and Brisbois 2003: vi, 7) Hence, the ability to manage and the capacity to appropriately reward these human resources is critical to the well-being of the sector and those it services.

The other factor to note is the highly gendered nature of nonprofit work. Because it is 'caring work' and often associated with greater employment flexibility, such as more part-time opportunities and other 'flexible' work arrangements, it is seen as particularly suited to attract women. The majority of the workforce is generally female. For example, one study reported over 80 percent of Toronto's nonprofit sector labour force was made up of women workers (Zizys 2011: 10). The gendered nature of the work and labour force also reinforces the undervaluation of nonprofit work (Cunningham and James 2011: 230; Baines 2011).

The importance of nonprofit service delivery for government financially supported social and human services has grown significantly over the last number of decades. It constitutes an important, and within urban regions, dense network of nonprofit service providing agencies as an integral part of Canada's mixed social economy of such provision (Evans and Shields 2010). The funding of the NPSS is very dependent upon government revenue sources, with generally 80 percent or more of funding coming directly from government contracts (Eakin 2001: 5 ; 2007). Due to a pattern of expanding needs in the context of growing polarization, and the negative impacts of underfunding and insecurity on the financing of nonprofit agencies delivering support services to communities and vulnerable populations, nonprofit service providers have come to be characterized as operating as part of a "precarious sector".

Contracting-out is part of a larger strategy of neoliberal governance and "right-sizing" the social state to minimalist and targeted provision. The neoliberal approach to governance is one that makes use of community as a policy instrument in an effort to minimize government support and funding for 
social needs (Rochefort et al. 1998). The goal is to download responsibility for services and care previously provided by the state onto local levels of government, nonprofit bodies, communities and families, "a process known as responsibilization" (Kelly and Caputo 2011: 11). The idea is to break so-called government 'dependency traps' and to tap into a latent self-reliance and self-help ethos; in essence "responsibilizing citizens" to tackle their own social needs in their communities (Ilcan and Basok 2004). For neoliberals, this allows for the shrinking of the state and the privatization of social care onto the local and community level (Shields and Evans 1988). Neoliberals seek to absolve upper levels of government from much of their responsibilities for social supports, appealing to community, charity, family and friends to "provide supports to absorb or offset income insecurity" (Neysmith et al. 2005: 144; Evans et al. 2005: 78).

\section{APPROACH}

Our account of the state of nonprofit sector precarity draws upon key observations and findings from: 1) an emerging literature on service providing nonprofit agencies; 2) an on-going in-depth study of precarity using qualitative interviews from a research project with Toronto-based workers and managers in the sector (see: PEPSO, nd); and, 3) survey data from a 2013 Ontario Nonprofit Network sponsored survey of nonprofit organizations in the province entitled Shaping the Future (McIsaac et al. 2013b), as well as some initial results of a "State of the Sector" survey sponsored by the Ontario Ministry of Citizenship and Immigration (MCI 2013). These survey findings allow us to draw broadly representative empirical evidence, while the sampling from in-depth interview material enables us to identify dominant issues connected to precarity in the NPSS and to draw examples of the actual 'lived experiences' of nonprofit workers and managers. The qualitative interviews give us the ability to tap into the deeper meaning behind the numbers regarding the dynamics of the multiple and overlapping kinds of precarity within the nonprofit sector.

The intent of the paper is not to draw definitive conclusions on the impact and consequences of nonprofit precarity. Rather, it seeks to identify and document the broad nature of precarity in the sector, detect emerging themes related to precarity, and more generally, to draw attention to the value of looking at the NPSS in assisting us to better understand the meaning and significance of the phenomenon of precarity in a broader sense.

\section{THE STRUCTURING OF NONPROFIT PRECARITY}

Precarity has become the centre of considerable attention, especially since the publishing of Guy Standing's book The Precariat: The New Dangerous Class (2011). Standing ties precariousness directly to changing employment relationships and 
more specifically to the formation of a new insecure and disposable underclass in the making-the 'precariat'. There has been considerable and heated debate regarding Standing's position (see: Breman 2013) but which is beyond the scope of this paper. We use the concept of precarity and its associated impact on employment as well as other societal structures more broadly than does Standing (2011) and some other scholars (Vosko 2010). For example, while others have linked precarity almost exclusively with low income groupings (and it is clear that precarious forms of employment are felt the most negatively here) it is also the case that insecure forms of employment have occurred and are increasing in middle and professional parts of the class stratum as well. Also, as in the case of the NPSS, precarity is far more than an employment phenomenon but also comes to be structured into other social formations, as we discuss below.

Precarity, in essence, relates to a situation where there is a lack of predictability and security. This often has negative repercussions with regard to both the material and psychological well-being of those impacted by precarious circumstances. Precarity tends to foster conditions of vulnerability, instability, marginality and temporariness. Precarity is manifested in the NPSS in various ways. In particular, it is expressed in high levels of job insecurity experienced by those working in the sector both on the front-line and in managerial positions, since the continuance of employment for so many workers is dependent primarily on short-term contract financing. As a contract dependent sector, the very nonprofit organizations themselves exist under a continuous threat of defunding, placing their on-going operation on a kind of temporariness footing (Shields 2014). As a senior manager in one multi-service agency with a large immigrant client group observed, "We are always insecure. We are always losing funding and having to lay off." Questions regarding the financial solidity of such funding dependent organizations comes to be a constant refrain. Such challenges to the organizational stability and employment continuity of the NPSS directly and negatively impacts clients and communities. Lack of continuity and instability in delivery of services creates service gaps. The programs are vulnerable to funding restraint and even elimination, particularly in the context of austerity and elevated need due to uneven growth and widening societal disparity. Cut to the bone, nonprofits find it increasingly challenging to maintain, let alone to strengthen, community connections.

The central factors that foster precarity in the NPSS are the funding and accountability regime and the neoliberal political foundation upon which it rests, that structures the organizational, employment and service system for the NPSS. The way in which nonprofits' publically provided services are financed profoundly changed beginning in the 1980s in Canada with the advent of neoliberal approaches to government and public administration. Not only was there a movement away from direct state provision of services to alternative and discounted third sector service delivery, but the funding structure that supported nonprofit providers shifted from core/base to project-based contract financing. 
The characteristics of the 'project funding regime' that separate it from the core funding model are significant. First, core funding tended to be long-term and relatively stable while project funding is short-term (generally yearly) and unstable, since it is built upon a competitive bidding process on service delivery contracts issued by government. Compelling competition among nonprofit organizations is intended to marketize caring services and drive down costs in a bid to get the 'best value for the dollar'. The concern is that it also easily leads to a 'race to the bottom' dynamic among nonprofit contractors (Cunningham and James 2011: 229).

A second feature is that core funding gave organizations considerable latitude in terms of how government dollars could be spent. This allowed nonprofit organizations to not just spend on direct program delivery, but also to use funds to support the operational and overhead costs of the organizations that are necessary to actually deliver programs. It further empowered nonprofit organizations to use some resources to build links into the community and become vehicles through which community members could exercise voice for expressing their concerns and interests to the larger society and government. Project funding, by contrast, very narrowly prescribes how funding can be spent -that is to say only on direct program costs. This has resulted in an underfunding of overhead costs, and severely compromised the financial stability of the infrastructure and ongoing operational budgets of nonprofits. This system also enables government funders to exert considerable control over the way contracted nonprofits provide services (Gibson et al. 2007; Clutterbuck and Howarth 2002) and ultimately how they connect to communities. The project funding regime attempts to transform nonprofits into one dimensional service providers operating from a business model of delivery. The idea of nonprofits as socially active organizations in their communities that also engage in advocacy roles is rejected. Such advocacy is seen to be a case of 'special interest' activities which government funds should not be associated with. These attitudes have certainly fostered an environment of 'advocacy chill' in the NPSS (Shields 2013; Evans and Shields 2014).

Accountability is the third distinguishing characteristic between funding systems. Previously the relationship between the state and nonprofit providers was one that tended to be guided "by bonds of trust", not highly structured contracts with taxing and rigid accountability systems, that offered "nonprofits considerable autonomy in how they constructed and delivered programs supported by public funds" (Evans et al. 2005: 76). While the concept of 'partnership' is employed to describe the new relationship between state funders and nonprofit service providers, under the neoliberal program financing regime the reality is that there is little that is reciprocal in these relationships. Rather, they are uni-directional, top down reporting mechanisms that are tightly linked to narrow market-based efficiency measures. Any idea of the accountability responsibilities that nonprofit providers owe to the communities they serve is 
conspicuously absent within this model. As Evans et al. note: “The benign language of 'partnership' hides a steeply hierarchical and centralized relationship of power embedded in a contractual arrangement between the state and those agencies increasingly responsible for the delivery of public goods and services" (2005: 78).

Finally, core funding is associated with the Keynesian approach to governance, while program financing is a product of neoliberal governance models. Keynesianism embraced policies that sought to provide a balance between the role of government, business and civil society actors in shaping societal consensus. Through relatively robust social policy measures a form of "limited inclusion" and security was brokered. Under neoliberalism, by contrast, a "markets knows best" logic for societal resource allocation has been embraced, resulting in a shrinking welfare state and its protective shield and a 'survival of the fittest' environment with growing inequality and insecurity, and a transfer of risk on to workers, families and individuals (Burke et al. 2000). This represents a "flexible just-in-time" system of provision of stripped-down publically supported services. Under the neoliberal project funding regime the NPSS has become a key component of an increasingly hollowed out welfare state and ever more contingent social provision of supports. As state provision of the "social safety net" has been eroded, marginalized populations have turned increasingly to the NPSS to meet their needs. But this demand has increased just as the sector's capacity has been threatened, in large measure because of this very restructuring (Evans and Shields 2010). As noted above, this fosters precarity at various levels.

Under neoliberalism the NPSS relationship with funders and the civil service that manages the connection have come to be largely structurally determined, fostering rigid relationships between funder and the nonprofit service provider. This means that civil servants who often see the negative and dysfunctional aspects of this funding system on nonprofit providers, and those they serve, find that they have their hands tied in terms of adjusting the workings of the relationship along more functionally beneficial paths.

\section{CREATING PRECARIOUS EMPLOYMENT RELATIONSHIPS IN THE NPSS}

These funding structures affected employment relationships within the sector profoundly. Evidence of this can be found in a recent survey. The overall survey reported the distribution of the paid workforce in 2012-13 in Ontario nonprofit social service organizations - the core element of nonprofit organizations profiled in this paper. In doing so, it indicates that about 48 percent was made up of full-time employees, 30 percent part-time, and 21 percent seasonally-based employees (MCI 2013: 34). Significantly, 'full-time' workers were less than half of this workforce. Moreover, given the sector's reliance on short-term and unstable contract funding, all categories of employment in this sector are subject to high 
levels of insecurity. This, in effect, imbeds an employment structure of 'permanent temporariness' (Shields 2014) into the DNA of the sector. The employment profile of the nonprofit sector places it in the vanguard of the shift away from the standard employment norms of the past to the more flexible and contingent employment forms of the new labour market. As a recent Mowat Centre report notes:

[...] there is a sense of decline in employment stability. In the nonprofit sector, particularly that part of the sector that relies heavily on public sector funding, this is experienced as a result of fiscal pressure of governments and the resulting move away from core funding to project-based funding. This reality shapes employment in the sector, and contributes to part-time and contract employment, lower wages, and limited access to benefits and pensions (McIsaac et al. 2013b: 15).

Among the top labour force retention challenges are the noncompetitive wage and salary and lack of career mobility paths in the sector. It has additionally been found that young people are not attracted to nonprofits because they very often fail to consider them 'real jobs' (McIsaac et al. 2013a: 21, 23).

In terms of the NPSS workforce, this situation has meant increased instability. For example, under-funding and a lack of long-term financing by definition translates into employment insecurity, increased workloads ('doing more for less'), lack of promotion ladders, lower wages and poor benefits. In short, much of the work in the sector has become more precarious and flexible. As noted in a Toronto nonprofit sector report: "Despite its social and economic contributions, this sector is known to pay low wages and benefits to workers. Any organization with consistently low wages runs the risk of losing its human capital to other organizations with higher wages" (Community Social Planning Council of Toronto and Family Service Association of Toronto 2006: 6). This situation is compounded by more recent austerity measures where government funding to the sector has been further restrained and already low wages eroded further by the failure of sector wages to keep up with inflation through wage restraint and freezes (Cunningham and James 2011: 230). Because there are very limited detailed surveys of the nonprofit sector it is difficult to get precise information of the wage/salary levels and other working conditions in the NPSS. Our own qualitative investigation, however, reveals that the compensation levels stand considerably below public sector employers and in many cases the most temporary workers receive wages only modestly above minimum wage. Stagnate wages/salaries in the NPSS due to years of flat lined funding is causing significant financial hardship for nonprofit employees.

At the same time, various forms of social financing like the promotion of social enterprise and social impact bonds are held out as solutions to the fiscal pressures faced by the NPSS. Social enterprise involves nonprofits setting up 
their own side businesses to generate additional revenue. Social impact bonds are new public-private partnerships centred around both financing and service delivery for the nonprofit sector. These new funding paths are pushing nonprofit service providers to be more market reliant and entrepreneurial and less 'dependent' on government funding for programming. The end result is an even more precarious sector where the new funding streams pose more risk than benefit (Joy and Shields 2013; McHugh 2013).

\section{EMERGING THEMES}

Our literature review and interviews with nonprofit workers and managers uncovered many additional themes which relate to nonprofit related precariousness. Some examples follow.

\section{STRESS}

A core theme that runs strongly through the interviews is the high levels of stress that is produced by precariousness. While most employees voiced their love of the helping nature of their work, they also expressed the strains resulting from the increasing instability of their jobs and the reality that the cuts to program funding for clients makes their work far more challenging. As one frontline worker noted: "And I feel good. It's challenging, it's hard, stressfulbeyond the word stressful!" A female middle manager went on to talk about the stress that comes from the pressure on nonprofit staff to make up out of their own personal finances and through extra fund raising for expenses to support their clients due to government funding shortfalls:

[...] most of the time we're putting money from our pockets and then it's always that stress and we're all in our twenties, early thirties and either in university or recently graduated, so it's not like we have a lot of money throwing around. It's that stress of not having the money and trying to make ends meet from ticket sales and trying to find sponsors and stuff. A lot of it is the money.

Stress and worker burnout is a direct consequence of "rising demands and insufficient resources, disillusionment and loss of independence as organizations experience mission drift in response to demands of funders, job insecurity and low pay" (McMullen and Brisbois 2003: 6).

Often our interviewees revealed that this stress came to be manifested in health related problems. As one nonprofit social service worker expressed her reality:

[...] I've had breakdowns at work, you know other pieces that have fallen apart because of the precariousness ... this year I managed to ... cobble some consultancy work together but didn't have enough to continuously sustain 
myself so I had to make some tough decisions around my housing [...] All of 2009 I was battling stress related autoimmune issues and this year I've been battling a different set of autoimmune issues, like my hair is falling out. I have rashes and hives that are, like magically appear. So yea, the woman at work who is responsible for HR has watched me half break down.

Such negative health-based consequences of precarity are increasingly coming to be recognized and documented (see for example: Lewchuk et al. 2011; Gibson et al. 2007). Moreover, the broader emotional toll that precarity takes upon the household is well identified in the It's More than Poverty report (PEPSO, 2013: 7980). A female visible minority youth worker expressed the pressures related to friends, family and society associated with her nonprofit precarious employment in this way:

[...] the keeping up with the Jones', pressure of you having a stable job and you don't have a stable house and when are you going to get married and have kids.

... Some of it is verbalized pressure and some of it is non-verbal pressure.

\section{SEARCHING FOR SECURITY AND PREDICTABILITY}

The theme of insecurity and built-in temporariness (Shields 2014) stand out as a dominant variable within the literature and interview sources. A manager from nonprofit social services summed up her assessment of how the program funding regime is negatively transforming the nonprofit sector: "It is a precarious sector and we are really in danger of becoming ... cheap government services with all the accountability of government and none of the infrastructure and stability."

What is also interesting is that the NPSS worker has in common much of the precarity of the clients they serve. The sector's workforce in many instances is actually drawn out of the populations that are serviced by these organizations. This connection became very evident in the interviews with nonprofit workers we conducted for this research. For example a foreign-born female immigrant settlement worker identified the challenge of serial contingent employment endemic to the nonprofit sector, as well as in the community she serves. She observed:

I was employed on contract work for months full-time as a community worker at a Community Health Centre but the pay was very poor. After that I found another job as a settlement worker for 8 months as a contract position. Once this contract expired, I found my current part-time employment, but even though it is part-time, it is a 1-year contract position.

Accepting a part-time position with the 'stability' of one year funding was preferable to shorter-term full-time work. In addition, a female visible minority 
youth worker noted: "[...] and see it's not about the money it's more about that I just want some guarantee, and it was just so loose and it was a nightmare." One of the factors that becomes most important for this is the necessity, as this worker identified, for "[...] the right amount of notice so that people's lives can continue going forward as seamlessly as possible [if there is going to be a layoff]".

The lack of predictability in terms of work take a toll on employees' lives and it creates the kind of precarious workforce that is often made up of vulnerable populations. This precarity and vulnerability means that organizations face serious challenges in undertaking planning for the future, as staff are unlikely to be around to actualize these plans or feel they have the overview to set goals for a very unstable future. This also means that most agencies have few staff with any institutional memory, making continuity very difficult. These points are spelled out by a female service worker:

When I was making $\$ 1,800$ a month there was one month I was not paid; they were closed in August. How do you think I lived for that month? I attended a meeting and this woman asked how can you be doing strategic planning with this organization when they have four staff and 15 women working out of that space and they are all women of colour, disabled, queer, trans, all this representation and of this framework but they are all contract workers. They all have no rights and they are all in precarious employment and you cannot do strategic planning with that kind of organization.

Since the project funding regime only finances independent projects, workers must apply for funding several times a year. Funding delays are common and the funders expect that the project is carried out on time, regardless of the organization's financial struggles to accomplish this. Though employees are not always paid on time they are still expected to continue their duties. Writing grant proposals is very stressful for employees, as a lot of effort has to go into them, yet success rates are low. Even when proposals are accepted, funding can take months to negotiate. Funding delays may also result in temporary layoffs while funding gets finalized. Nonprofit staff are very often given notice of layoff. Links with funders were also precarious with reports of inter-organizational relationships that existed over email rather than in person. Contacts within the funding bodies were also transitory, with personnel reportedly moving around after only a year in their post. Further, contact with these officials by agency staff suggested that the priority of government officials was predominantly cost. All these hurdles contribute to an unstable environment to work in, increasing stress, and other resulting financial burdens for paid staff.

\section{THE BURDENS OF ACCOUNTABILITY}

Problems of excessive accountability came through very strongly in the interviews, particularly among nonprofit managers. These accountability 
requirements meant organizations had to justify their service delivery by requiring employees to take on extra responsibilities to carefully and mechanically measure the outcomes of their projects. The employed front-line workers might be lacking in administrative and report-writing skills, which causes them to limit their time with clients. Furthermore, the accountability system, because of its use of scarce nonprofit resources and the strict rules around how funding dollars can be spent, worked against agencies' abilities to build deeper connections in their clients' communities, as more flexible funded services cannot be resourced through program financing rules.

A senior manager of a multi-service agency recounted the challenges of these government accounting and reporting demands:

Trying to develop a coherent way of even keeping data and evaluating, when everybody has different demands and different requirements, has always been tough, but I think even more so now when they're demanding more information and that kind of thing. Not even accountability, just more that micromanagement thing.

Likewise another manager of a social service nonprofit commented that:

I feel that paper tracking is great but it requires so much time. It does show case numbers but there's other ways to evaluate what's happening versus just ticking off numbers. Facts and data are great but they take more time to collect and I think that time takes away from our ability to serve our community in a better way.

However, there are others who are of the view that while the data could be a valuable analytical devise, that government funders in actuality rarely make any use of it.

There is considerable concern expressed that current systems of accountability are overly burdensome on nonprofit organizations, consuming scarce human and financial resources on activities focused more on controlling and directing how nonprofits run and deliver their programs than on actual program outcomes. Interviews revealed that it was not uncommon for accounting and reporting activities to absorb twenty percent or more of the work time of service delivers, and even more for managers, an amount that has grown significantly over the years. This was seen as taking away from the time and quality of direct services provided to communities, adding considerably to the work burdens and stress of nonprofit staff, as well as imposing procedures that reduced the autonomy of organizations and staff to tailor service delivery to actual needs of clients. The imposition of businesslike models of accountability and management compels nonprofits to think ever more in narrow, economistic, business terms. For example, nonprofits are expected to meet quantitative goals such as benchmarks, efficiencies and doing more with less. Much of this is 
accomplished by the simplification and standardization of work; via computerized programs and standardized forms (Baines 2006). Standardization has led to a loss of discretion, less face to face time with clients and more emphasis on 'efficiency' and 'accountability' of workers to management. Community-centred caring approaches to work are generally sacrificed on the altar of accountability and efficiency.

\section{A LABOUR OF LOVE}

Nonprofit work takes place in a mission-based sector and those who work and volunteer for NPSS bodies are, in large measure, attracted by an ethos of caring and giving to their communities (Cunningham 2008). The hold of the mission for the sector workers and managers is powerful and acts as alue that binds them to an increasingly precarious work environment, helping to facilitate the normalization of precarity within the sector. Too often the work of the sector has come to be viewed narrowly as being primarily a 'labour of love' which is seen to be a reward in and of itself. It has even been argued that compensation in the sector is purposefully structured to be inferior than in other sectors as a way of ensuring that those attracted to it have done so for the correct motivations, and willingly trade off poorer compensation outcomes for the privilege of doing mission-driven caring work (See: McMullen and Schellenberg 2003: 15). Cunningham has stressed that it is important that we understand the employment relationship in the sector as a 'psychological contract' with an ethos of caring at its centre (2011). This is eroded, however, as business-oriented approaches and their negative consequences are foisted on the sector. Leaders in the sector agree that organizational missions and values are important factors in attracting employees but that this is not sufficient (McIsaac et al. 2013b: 22) to provide a sustainable road to retention as the underlying structural challenges of poor pay, overwork, burnout and employment instability dislodge the 'mission grip' that initially attracted individuals to the sector.

The fact that many nonprofit agencies endeavor to create work environments that attempt to be caring and respectful to staff, even in the context of funding cuts, and the strong hold that the nonprofit culture and ethos has on those who do this kind of work, remains an important bonding agent for workers in the sector. This point is clearly revealed by a female part-time contract worker:

I think the organization is very supportive of people's personal lives as well as professional career paths and I think there's a lot of flexibility and accommodations that are provided. I think that's what keeps people on. In spite of changes and restructuring and cut backs and funding freezes, there's something else happening within the culture of the organization that's keeping people here and keeping them working as hard as they always have. 


\section{RELYING ON VOLUNTARY LABOUR}

A major feature of the NPSS has been the need for the sector to manage its labour costs in the context of a funding squeeze. In fact, 3 out of 4 nonprofit organizations report significant challenges in having enough revenues to meet ongoing efforts to reach their objectives. This translates into a serious parallel problem, identified by the sector as a difficulty in planning for the future (MCI 2013: 61, 63). These challenges compel nonprofit organizations to increasingly rely on voluntary effort in order to help make ends meet. Trends reveal, in fact, that labour from voluntary contributions is greatly outpacing the growth of the paid labour force in the Ontario nonprofit sector (MCI 2013: 38).

The restructuring of the NPSS due to funding cuts and the institution of business practices have 'thinned out' the sector and many services agencies have moved to flexible models of staffing, much of which includes unpaid work in the form of volunteer hours and unpaid overtime (Baines 2004). Because of their commitment to social justice and the agency, many managers also put in hours of unpaid overtime. Some recognize the contradictions of this situation. As a social services manager noted,

It's not a nine to five job, definitely not. We do claim our overtime, I would say I don't claim all my overtime. I claim overtime that's critical that I did that overtime to get that deadline. Or, if we have events that we have to go to, I think most of management doesn't claim all their overtime and that goes with the job ... I think most of us that do this work, it's wanting to improve the quality of life for people, it's about social justice and with that it becomes that extra time.

Virtually everyone we interviewed working in the sector had similar stories about the necessity and moral pressure they felt to donate their unpaid time to serve needy clients, given the organizations' financial squeeze.

\section{NONPROFITS AND UNIONS: THE LACK OF A COUNTERVAILING FORCE}

The nonprofit sector has relatively low union density, with one Ontario nonprofit survey indicating only an overall 14 percent density rate, although the subsector of social and human services recorded a rate of 27 percent (McIsaac et al. 2013b: 14). These levels, however, are considerably below unionization rates for the public and para-public sectors that are the other providers of publicly supported services. Unions are important in providing some measure of protection against employment insecurity, low wages and poor benefits and working conditions. Unions act as a countervailing force to pressures from marketization and business driven restructuring. The limited and fragmented presence of union protections provide little relief for most nonprofit workplaces. Moreover, even where they have a presence, collective resistance is harder to 
undertake because of difficulties in attributing changes to terms and conditions to the immediate employer when purchasers are dictating financial conditions (Marchington et al. 2005).

A female nonprofit service worker revealed her frustration with the lack of protections around employment security in these words:

I have been with the agency for ten years but we are not unionized and our funding comes from all sources. The Feds, the province and the city. [In] My particular job the funding comes from the Feds. It goes down to the province and then to the city and then they divvy it out to us so even though it it's federal money the city controls it. That's precarious because we are never sure whether we're going to get funding. Recently we've been told that no job is guaranteed.

\section{COMMUNITY AND THE CHALLENGE OF 'RESPONSIBILIZATION'}

Serving the clients and community is a driving force behind why most of those who are employed in the NPSS are drawn to work in the sector. This is clearly articulated by one female multi-service agency manager when asked about what she liked about her job: "The value that you get back, the benefits that you see in the community is the biggest reward in itself." However, those we interviewed also point out growing problems with the services they are able to offer because of government funding cutbacks. Significantly, one of the issues that came up were cuts to items such as public transit expenses, free childcare while utilizing services, and the ability to offer a bit of light food for clients. The cutting of such supports to clients in the name of austerity has had dramatic and negative impacts on community access to programming. As our aforementioned manager laments:

Yes, the funding has also impacted the residents in the sense that there's no more accommodation ... for them. TTC [public transit] tokens, for example, transportation support ... before we received two tokens-one for coming, one for going - while now they might receive one every other week because there's just no sources to buy TTC anymore. Or even the snacks, they don't have enough money to eat food at home or have breakfast and when they come to our programmes, they rely on having those snacks and refreshments available and now that's limited to crackers and juice whereas before we might have fruits and such. That affects their willingness to wanna be in the programme because, yes, they're there to learn ... but those two foundational - transportation and foodwas one of the things that encouraged them ..."

For marginalized communities these small and financially modest supports are critical to open the door to service use. For individuals and families often living off survival jobs even paying for public transport to get to programming can be a formidable barrier. 
A senior nonprofit executive articulates her projections about the erosion of nonprofit organizations' close bonds with communities they service because of the imposition of continuous program restraint and business management models of operation promoted by policies aimed at shrinking the state and responsibilizing care downward. As she notes:

I think a lot of the organizations ... who do more than service delivery and have a real community base, I think that's gonna be lost. I think it's gonna be much more service delivery and business model and providing efficient, effective services. Here one of the things, and I'm sure you're gonna hear it from people, one of the things that we really value and really are proud of, is how we work with the community. So many people talk about coming here and it feels like a second home, and we have that ability to support people beyond just providing specific programmes, that more holistic thing. I could see some of that going, because it's gonna be very cost-effective, whatever, all that, just do with the service. As people say, most people if they need the service, they'll get it, they don't really care who's giving it.

Nonprofit community-based services are far more than 'just the service.' They are about a holistic approach to caring that engages with the community to assess and address needs and represent communities. The neoliberal model of service delivery strips away this holistic approach to 'caring' leaving in its place a thinned out model of service. Such a devalued approach to 'caring' fosters community marginalization and exploitation (Glenn 2000: 84). 'Responsibilization' strategies to care that run through the NPSS funding relationships with government transfers risks onto nonprofit organizations, their clients and to the communities they serve. Precariousness is an inevitable product of such circumstances.

\section{CONCLUSION}

The problem of precarity is a serious and growing phenomenon closely associated with the deepening of neoliberal approaches to the running of markets, societal relations and government. The spread of precarity has been recognized as operating at the level of the labour market, as standard forms of secure employment have come to be displaced by the rapid advance of new insecure contingent work forms. The salience of the issue in Canada was brought home by the careful documentation of the presence of employment precarity and its negative consequences in the It's More than Poverty report (PEPSO, 2013) and the strong reception it struck with the public through wide media coverage.

By expanding our gaze to the workings of precarity in the nonprofit sector we are able to deepen our understanding of the phenomenon. The deficit in funds, security and dependability at each level intensifies and reinforces the vulnerability of the next. The multilayered and self-reinforcing character of 
precarity's operation at the level of the workforce, organizational and community level within the nonprofit service providing sector provides valuable insights about the depth and reach of precarity beyond the employment relationship that are worthy of further exploration. Through the use of in-depth qualitative interviews with nonprofit management and workers, recent empirically-based studies, and a careful reading of an emerging nonprofit literature, we offer some initial steps in this direction.

\section{NOTES}

1 This paper was made possible by the support of funds from the United Way Toronto- McMaster University SSHRC CURA project on Poverty and Employment Precarity in Southern Ontario. John Shields would also like to acknowledge Massey College at the University of Toronto where he resided as the Ryerson Fellow (201314) for office space and support.

\section{REFERENCES}

Baines, Donna. 2011. Restructuring and Labour Process Under Marketisation: A Canadian Perspective. Pp.168-184 in Voluntary Organizations and Public Service Delivery, edited by Ian Cunningham and Philip James. London: Routledge.

--------. 2006. “Whose Needs are Being Served? Quantitative Metrics and the Reshaping of Social Services." Studies in Political Economy 77 (Spring): 193207.

-------. 2004. “Caring for Nothing Work Organization and Unwaged Labour in Social Services." Work Employment and Society 18(2): 267-295.

Breman, Jan 2013. “A Bogus Concept?" New Left Review 84(NovemberDecember). Retrieved July 112014

https://newleftreview.org/II/84/jan-breman-a-bogus-concept

Burke, Mike, Colin Mooers and John Shields. 2000. "Critical Perspectives on Canadian Policy". Pp. 11-23 in Restructuring and Resistance: Canadian Public Policy in an Age of Global Capitalism, edited by Mike Burke, Colin Mooers and John Shields. Halifax: Fernwood, Halifax.

Clutterbuck, Peter and Rob Howarth. 2002. Toronto's Quiet Crisis: The Case for Social and Community Infrastructure Investment, Research Paper 198. Toronto: Centre for Urban and Community Studies, University of Toronto, November.

Community Social Planning Council of Toronto (CSPC-T) and Family Service Association of Toronto (FSA). 2006. On the Front Lines of Toronto's Community Service Sector: Improving Working Conditions and ensuring Quality Services. Toronto: CSPC-T and FSA, July. Retrieved July 112014

http://socialplanningtoronto.org/wp-content/uploads/2009/01/on-the-frontlines_community-sector_july-2006.pdf

Cunningham, Ian. 2011. "Taking the Strain? The Psychological Contract of Voluntary Sector Employees Following Transfers of Employment". Pp. 136- 
152 in Voluntary Organizations and Public Service Delivery, edited by Ian Cunningham and Philip James. London: Routledge.

Cunningham, Ian and Philip James. 2011. "Public Service Delivery and the Voluntary Sector: Trends, Explanation, and Implications". Pp. 225-237 in Voluntary Organizations and Public Service Delivery, edited by Ian Cunningham and Philip James, eds. London: Routledge.

Eakin, Lynn. 2007. We Can't Afford to Do Business this Way: A Study of the Administrative Burden Resulting From Funder Accountability and Compliance Practices. Toronto: The Wellesley. Retrieved July 112014

http://www.lynneakin.com/frameset/images/LE_Docs/Reports/FinancingtheNon profitSector/WeCantAffordtoDoBusinessThisWay/we-cant-do-afford-to-dobusiness-this-way-ex-sum-colour_pdf

------. 2001. An Overview of the Funding of Canada's Voluntary Sector. Ottawa: Voluntary Sector Working Group on Financing, September.

Elliott, Larry and Dan Atkinson. 1999. The Age of Insecurity. London: Verso.

Evans, Bryan and John Shields. 2014. "Nonprofit Engagement with Provincial Policy Officials: The Case of NGO Policy Voice in Canadian Immigrant Services." Policy and Society 33 (2): 117-127.

Evans, Bryan and John Shields. 2010. "The Third Sector and the Provision of the Public Good: Partnerships, Contracting, and the Neo-Liberal State". Pp. 305318 in The Handbook of Canadian Public Administration, second edition, edited by Christopher Dunn, ed. Don Mills, ON: Oxford University Press.

Evans, Bryan, Ted Richmond and John Shields. 2005. "Structuring Neoliberal Goverance: The Nonprofit Sector, Emerging New Modes of Control and the Marketisation of Service Delivery." Policy and Society 24(1): 73-97.

Gibson, K., O'Donnell, S., and Rideout, V. 2007. The project-finding regime: complications for community organizations and their staff. Canadian Public Administration 50(3): 411-435.

Glenn, E. 2000. Creating a caring society. Contemporary Sociology. 29(1): 84-94.

Ilcan, S. and Basok, T. 2004. Community government: voluntary agencies, social justice, and the responsibilization of citizens. Citizenship Studies. (8)2: 129-144.

Joy, Megan and John Shields. 2013. "Social Impact Bonds: The Next Phase of Third Sector Marketization?." Canadian Journal of Nonprofit and Social Economy Research/Revue canadienne de recherche sur les OBSL et l'économie sociale 4(2): 3955.

Kelly, Katharine and Tullio Caputo. 2011. Community: A Contemporary Analysis of Policies, Programs, and Practices. Toronto: University of Toronto Press.

Lewchuk, Wayne, Marlea Clarke and Alice de Wolff. 2011. Working Without Commitments: Precarious Employment and Health. Montreal: McGill-Queen's University Press. 
Marchington, M., Grimshaw, D., Rubery, J. and Willmott, H. (2005). Fragmenting Work: Blurring Organizational Boundaries and Disordering Hierarchies. Oxford: Oxford University Press.

McIsaac, Elizabeth, Stella Park and Lynne Toupin. 2013a. Human Capital Renewal in the Nonprofit Sector: Framing the Strategy. Toronto: Mowat Centre, University of Toronto.

------. 2013b. Shaping the Future: Leadership in Ontario's Nonprofit Labour Force. Final Report ONN Human Capital Renewal Strategy: Phase One. Toronto: Mowat Centre, University of Toronto.

McMullen, Kathryn and Richard Brisbois. 2003. Coping with Change: Human Resource Management in Canada's Non-profit Sector. No. 4 Ottawa: Canadian Policy Research Networks. Retrieved July 112014 http://www.cprn.org/documents/25445_en.pdf

McMullen, Kathryn and Grant Schellenberg. 2003. Job Quality in Non-profit Organizations. Ottawa: Canadian Policy Research Networks. Retrieved July 11 2014 http://www.cprn.org/documents/16694_en.PDF

McHugh, Neil, Stephen Sinclair, Michael Roy, Leslie Huckfeld and Cam Donaldson. 2013. "Social Impact Bonds: A Wolf in Sheep's Clothing?" Journal of Poverty and Social Justice 21(3): 247-257.

Ministry of Citizenship and Immigration, Ontario (MCI). 2013. State of the Sector: Profile of Ontario Not-for-Profit and Charitable Organizations, Volume I: Overall Report. Toronto: Government of Ontario. Retrieved July 112014 http://www.citizenship.gov.on.ca/english/pp/docs/state_of_the_sector_overall_re port_volume1.pdf

Neysmith, Sheila, Kate Bezanson and Anne O'Connell. 2005. Telling Tales: Living the Effects of Public Policy. Halifax: Fernwood.

Poverty and Employment Precarity in Southern Ontario PEPSO. 2013. It's More than Poverty: Precarity and Household Well-being in the GTA-Hamilton Region. Toronto/Hamilton. Toronto/Hamilton: United Way Toronto/Poverty and Employment Precarity in Southern Ontario (PEPSO). Retrieved July 112014 http://pepsouwt.files.wordpress.com/2013/02/its-more-than-poverty-feb-2013.pdf

-----. Nd. Case Study 3: Precarity in the Community Services Sector. Retrieved July 112014 http:// pepso.ca/case-studies/case-study-3/

Richmond, Ted and John Shields. 2004. "NGO Restructuring: Constraints and Consequences." Canadian Review of Social Policy 53(Spring/Summer): 53-67.

Rochefort, D.A., Rosenberg, M., and White, D. 1998. Community as a policy instrument: A comparative analysis. Policy Studies Journal 26(3): 548-568.

Shields, John. 2014. "Constructing and 'Liberating' Temporariness in the Canadian Nonprofit Sector: Neoliberalism and Nonprofit Service Providers." Pp. 255-281 in Liberating Temporariness? Migration, Work and Citizenship in and Age of Insecurity, edited by Robert Latham, Valerie Preston and Leah Vosko, eds. Montreal: McGill-Queen's University Press. 
93 Just Labour: A Canadian Journal of Work and Society - Volume 22 - Autumn 2014

--. 2013. “Nonprofit Engagement with Provincial Policy Officials: The Case of Canadian Immigrant Settlement Services", 1st International Conference on Public Policy, Grenoble, France, June 26-28th.

Shields, John and B. Mitchell Evans. 1998. Shrinking the State: Globalization and the "Reform" of Public Administration. Halifax: Fernwood Publishing.

Standing, Guy. 2011. The Precariat: The New Dangerous Class. London: Bloomsbury Academic.

Statistics Canada. 2007. Satellite Account of Non-profit Institutions and Volunteering, 2007. Catalogue no. 13-015-X. Ottawa: Statistics Canada.

Vosko, Lea. 2010. Temporary Work: The Gendered Rise of a Precarious Employment Relationship. Toronto: University of Toronto Press.

Zizys, Tom. 2011. Not Working For Profit: A Labour Market Description of the NonProfit Sector in Toronto. Toronto: Ontario Nonprofit Network \& Toronto Workforce Innovation Group. Retrieved July 112014

http://www.workforceinnovation.ca/sites/default/files/Not $\% 20$ Working $\% 20$ For $\%$ 20Profit-\%20ONN\%20TWIG\%20Report\%20May\%202011.pdf 